\title{
Approaching Literature with Linguistic Means: a Few Conclusions
}

\author{
Zsuzsanna AJTONY \\ Sapientia Hungarian University of Transylvania, Cluj-Napoca \\ Department of Humanities, Miercurea Ciuc \\ ajtonyzsuzsa@yahoo.com
}

\begin{abstract}
This paper is a follow-up of my research carried out on the interface area of language and literature, summarizing the conclusions that can be drawn from the approach of literary works with linguistic means. In my research I have analysed the dramatic works of G. B. Shaw with the help of the latest results of interactional sociolinguistics. After a thorough examination of the Shavian characters' verbal interaction focusing on the relevance of ethnic features (Britishness, for instance), this article discusses the legitimacy of linguistic methods in the interpretation of literary works.
\end{abstract}

Keywords: language, literature, semiotic perspective, interactional sociolinguistics, interdisciplinary approach

\section{Introduction, structure of the paper}

For those interested in applying linguistic methods to the study of literature an obvious procedure is to use the categories of linguistics to describe the language of literary texts. Literature, as Valéry said, 'is a kind of extension and application of certain properties of language' (quoted in Culler [1975], 2008: 64). The linguist, therefore, can contribute to literary studies by showing what properties of language [are] being exploited in particular texts and how they [are] extended or reorganized (ibid.).

In my research I have investigated the interface of language and literature analysing literary works with the help of linguistics, in particular, discussing the conversational strategies employed by G. B. Shaw's characters that shape their ethnic identity. In this paper I discuss the legitimacy of the linguistic approach to literary works in general, specifically referring to the Shavian plays as a corpus analysed with sociolinguistic means.

This paper attempts at summarizing the conclusions that can be drawn from the approach of literary works with linguistic means. Firstly, I introduce the 
main topic of discussion, literature, approached as a type of public discourse, a specific genre, also paying particular attention to dramatic discourse. The second part of the paper concentrates on relevant methods employed in the analysis of dramatic dialogues, in general, particularly highlighting the Shavian plays that have been analysed within the research. The final part of the article summarizes the main results of the research carried out on the interface of language and literature, emphasizing the relevance and legitimacy of the linguistic analysis in the approach of the above mentioned plays in particular, making reference to literature, in general.

\section{Literature-a type of discourse}

In my research I consider literature as one type of discourse, an identifiable type of 'genre', whether literary or not. Just as 'the lecture, a casual conversation, and the interview are all genres' (Traugott and Pratt 1980: 20), the novel, the short story or the drama are also different types of discourse. 'This broader view on genre is valuable in that it helps us conceptually to bridge the traditional gap between literary and non-literary discourse. It enables us to view literature as a particular range of genres or discourse type, that is, as a particular subset of the repertory of genres existing in a given speech community.' (ibid.)

Literature as a range of genres is public, not private, discourse. Additionally, because it is a written form of discourse, it can be read 'at a far distance in time and place from its origin' (idem, 21). Moreover, since the texts analysed belong to the dramatic genre (G. B. Shaw's plays), beside the ideational function of language (according to which language is used to convey experience and information about the context and is best exploited in poetry and prose), the interpersonal function of language is brought to the limelight. Drama is prototypically the literary genre composed almost entirely of face-to-face interaction between characters (Tan 1998).

\section{Relevant methods for the analysis of the Shavian plays}

The methods of analysis, which focus on the linguistic structure of the dramatic dialogue, belong to the domains of discourse analysis, conversation analysis and pragmatics, which deal precisely with face-to-face interaction. All these prove to be useful tools in analysing the meanings of utterances in (fictional) dialogues. Besides, politeness theory, which is also applied in the analyses, can illuminate the social dynamics and character interaction, while discourse analysis can shed light on aspects of characterization. 
Research shows that 'an increasing interest in the pragmatics of literary texts has been making itself felt across the disciplines of both literary sciences and linguistics' (Mey 2001: 787). Suffice it to mention the emergence of such salient works as Traugott and Pratt's (1980) Linguistics for the Student of Literature, the Interface Series of Routledge Publishing House and studies in the socalled literary pragmatics (e.g. Mey (1999), Toolan (1994), Fludernik (1993)). In addition, further research articles can be mentioned in this line, included in the journals of this borderline area like Text, Poetics, Journal of Literary Semantics, and especially Language and Literature, which covers the latest developments in stylistic analysis, the linguistic analysis of literature and related areas. These journals also provide firm evidence that the combination of literary criticism and linguistics is both legitimate and creative.

The language of literature is one of the most traditional applications of linguistics, 'one which has been given new impetus by the rapid new developments in linguistics since the development of generative grammar. At the present time, linguistic analysis of literature is one of the most active and creative areas of literary studies' (Traugott \& Pratt 1980: 19-20). Although linguistics is not essential to the study of literature, it can contribute to a better understanding of a text. It can help in raising awareness of why it is that we experience what we do when we read a literary work and it can also reveal how the experience of a work is in part derived from its verbal structure. Above all, however, linguistics can give the conscious reader a point of view, a way of looking at a literary text that will help them develop a consistent analysis, and prompt them to ask questions about the language of a text that they might otherwise ignore. Linguistics helps ensure a proper foundation for analysis by enabling the literary critic to recognize the systematic regularities in the language of a text. In this sense, we can use linguistics to construct a theory about the language of a text in the form of a "grammar of the text". In this way, linguistics forms an integral component of literary criticism.

Alongside this line of research, my study has examined the 'significance' of the literary text from a linguistic perspective, investigating its language from different points of view. In this sense, investigation has taken place on two levels:

1. the analysis of the language proper, of the linguistic choices the author (G. B. Shaw, in our case) makes, which draws no distinction between the literary text and other types of texts;

2. the analysis of the significance of such linguistic choices, which leads the critic to a deeper, more proper interpretation of the literary work.

The significance of linguistic choices is understood in two complementary ways:

(i) Firstly, the literary text is considered to be an answer to the everyday social and political questions of the playwright's time. In our case, Shaw's adoption of 
one of the ideological trends of the age (Fabianism, socialism) is transparent in the texts of the plays, in the characters' attitudes to certain social and political issues;

(ii) Secondly, the work shapes the ideological views of the time. In this sense, the literary work plays an active role in forming the ideology of an age. This point is especially salient in the case of Shaw's plays, as they have been influenced by the ideologies of the age, but they also influenced the critical thinking of the age.

Within this framework, the methodology of analysis applied to the plays is micro-sociolinguistic. The key problem in this field of linguistic research is always the origin and nature of the social valence attached to linguistic forms. Choices of form are primarily determined by the social characteristics of participants and setting. As Brown and Levinson (1987) point out, it is precisely in action and interaction that the most profound interrelations between language and society are to be found: this is the field of micro-sociolinguistics. In line with this approach, the Shavian plays are taken as an authentic socio-cultural linguistic corpus (Bucholtz \& Hall 2005). In this context, the social variables that shape the identity of the characters are related to their language use and social behaviour. Born from the writer's fictional world, the language these individuals use is characteristic of the time and society in which the author lived and created them. In this sense, my research has been an attempt to capture the typical sociolinguistic features of these literary figures who-though on the surface have nothing to do with real life at the end of the $19^{\text {th }}$ and the beginning of the $20^{\text {th }}$ century-basically are the 'children' of their creator's age, whether the action of the play takes place in the $16^{\text {th }}$ (Saint Joan), $19^{\text {th }}$ Century (A Man of Destiny) or right in Shaw's own time (Mrs Warren's Profession, Major Barbara, or Pygmalion).

By offering an ambiguous view of the created ethnic stereotypes, Shaw constructs and undermines at the same time his characteristically paradoxical plot and character treatment. My research has concentrated on all the conversational strategies the Shavian characters employ while they act like a typical specimen of their ethnic group or nationality, of their gender or their class, or exactly the opposite. The analyses pursued in the research not only capture these characters in their linguistic interaction with other characters, but, as their ethnical bias is revealed in ways other than language, it also seizes the way they utter certain sentences or make certain gestures, use body language, etc. In other words, the focus of my research has been to analyse how interacting participants use language, which - as a result - shapes their ethnic identity. However, because ethnicity is not neatly isolable from other facets of identity, it is necessary to consider the participants' positioning with respect to other types of group identity (e.g. gender, class, age), as well as personal and interpersonal identities that are adopted, shaped and abandoned in the course of the unfolding interaction.

Summing up, the methods of analysis of the plays are based on the interface of language and literature. The plays are approached from a micro-sociolinguistic 
perspective. Although I have followed the close analysis of the texts, concentrating on their different closures which lead us back to the age of structuralism, in my research I have applied post-structuralist, present-day methods, relying on the latest and newly emerging branches of linguistics: pragmatics, conversation analysis, Speech Act Theory, Politeness Theory and other methods of analysing linguistic manifestations of identity, and specifically, ethnicity.

It must be added that through pragmatics, linguistics extends its area of research towards sociology, anthropology, to the study of power relations and language ideology (in the sense discussed by Foucault and Barthes). In my analyses, however, I have remained within the area of linguistics (micro-sociolinguistics), by offering analyses based on cultural pragmatics. Thus linguistics provides a method of analysis, it steels us with a battery of concepts, which bridge the space between text and its ideological and sociological significance. The micro-sociolinguistic concepts employed in the analyses originally derive from the fathers of pragmatics and language philosophy; such concepts as Austin and Searle's 'illocutionary force', Grice's 'conversational implicature', further developed by Leech's 'interpersonal rhetoric' (as it appears in his Principles of Pragmatics), and Brown and Levinson's politeness theory. From the vast area of micro-sociolinguistic research we have chosen the method of conversation analysis, which is viewed as micro-sociolinguistic analysis. The discussion of the roles, identities, ethnicity that the different characters assume takes us to the realm of their language use, the field of socio-pragmatics (as Leech defines it in his 'interpersonal rhetoric'1), also incorporating Speech Acts, viewed as social transaction.

\section{Results-the relevance and legitimacy of the linguistic analysis in the approach of literature}

So far a great deal of research has been carried out concerning the Shavian plays from the perspective of literary criticism. However, I consider that linguistic methods can give a new perspective and offer a more rigorous approach to the literary text than literary methods, by offering a close analysis of the plays. I have approached them with post-structuralist methods, which are able to foreground subtleties of the literary text, which otherwise would remain unnoticed. I believe that precisely through the pragmatic approach, especially Speech Act theory, through inference and implicature, it is possible to legitimise and bring evidence

1 Cf. Leech (1983: 79) where he shows that both the CP (Cooperative Principle) and the PP (Politeness Principle) are required to account for pragmatic interpretations, and there is a need for a 'rhetoric', in the sense of a set of principles which are observed in the planning and interpretation of messages. 
for the claims of literary criticism. These methods have also led to other findings that only the linguistic analysis could bring to the surface. In order to be able to approach the Shavian plays relevantly, they are viewed as a micro-sociolinguistic corpus on which the characters' verbal behaviour, their face-to-face interaction can be followed and analysed.

Following our socio-cultural analysis of five Shavian plays I have come to the following methodological results:

4.1. The general semiotic perspective and within it, the structural approach to the Shavian plays has guided me to a new and relevant interpretation of these texts. According to the semiotic approach to texts, the intention of a text is never completely clear or obvious therefore it seems to allow for several possible readings. It is the structure of the text that steers the reader to comprehend certain elements in a certain way. Research has claimed (Kelemen 1998 following Eco 1990, 1992) that a text always contains all its possible readings. In order to correctly recognize the intention of the text, the reader's task is to use conjectures. These conjectures must be tested and confirmed by the text as an organic whole. If this is achieved, the reader has come to a pertinent interpretation. If not, new conjectures must be made until the text replies to them. The interpretation of a text is therefore a continuous dialogue between the text and its reader.

In my analyses of the verbal interactions of the Shavian characters I have tried to maintain this continuous conversation with the text. I have demonstrated that the author's intentions are coded into the linguistic or other textual strategies employed in/by the text. As a reader of the Shavian texts, as the addressee of the author's intention, I have kept these strategies in mind all along the process of interpretation. All the textual (semantic, stylistic, semiotic, structural) but also ideological, cultural and historical constraints, as integral parts of the internal coherence of the text, are planted into it. If we are to provide a relevant interpretation of these texts, all these aspects have to be taken into account.

In this line, in those cases (Arms and the Man, The Devil's Disciple, Caesar and Cleopatra, John Bull's Other Island) where the play has an ethnic reading, i.e. it is ethnicity as a structuring element that the play is constructed around, parallelisms could be drawn between the different versions of Britishness. In that case where the play cannot be read as a discourse about British ethnic identity (Pygmalion), parallel identities disappear. Therefore a new conjecture had to be made, and the intertextual reading of the title and, consequently of the play, gave a clue to its relevant interpretation. Though Britishness is not the main structuring element of Pygmalion - though ethnic references are to be found in the verbal manifestation of some of the characters-, this text has also been investigated because it offers a larger perspective on Britishness, opening to the more general framework of 'Anglo-Saxon attitudes'. Therefore this play has been interpreted as an overtly 
intertextual play about the condition of the creator within a specific historical and social context, intertextuality being offered by the title of the play itself.

4.2. The ambiguity and paradoxical attitude in the Shavian character treatment has some implications for the theory of stereotypes and schema theory, as well. The analyses of the British stereotypes in the selected plays have confirmed the already-known theoretical claim that stereotypes act like schemas, in so far as they are perfectly compatible with all the elements of the category. Consequently, its boundaries can be extended and the schema (in our case, the stereotype) will still remain unharmed. This is in line with the claim (Mills 2003: 202) that stereotypes themselves do not necessarily exist in any 'real' or 'material' form. Rather, they function as hypotheses made on the part of the speakers about what norms and assumptions function within that particular context or community of practice. In his plays, Shaw goes even further. He challenges the boundaries of ethnic stereotypes in such a way that not only does he maintain but he also contests them, for the sake of intellectual adventure but probably for an educational purpose as well.

The other theoretical conclusion regarding stereotypes is the confirmation of the idea that though stereotypes may change due to different social, cultural or historical circumstances-since they assume incomplete factual knowledgethey still remain valid over time.

Strongly connected to this validity concept, our analyses have also confirmed the presence of the same ethnic stereotypes produced by cultural historians (for instance, Doyle 1989, Lucas 1990 and Easthope 1999), sociologists and cultural anthropologists (Fox 2005) or journalists (Paxman 1998). Ample footnotes have made references to them. The stereotypical ethnic traits are thus verifiable in the language strategies of the characters, as the analyses of the character's verbal behaviour have revealed it.

Obviously, the circle of plays analysed could have been extended, but we believe that these five plays can be considered as models of Shaw's pattern of character creation and simultaneous display of ethnic stereotypes and counterstereotypes. The different varieties of the British stereotype prove to be each other's paradoxically complementary elements. Our analyses have discussed the 'degree of Englishness' the characters exhibit in their speech, behaviour, manner and customs.

4.3. The linguistic methods proposed for analysis of literary texts have thus proved to be relevant. The approach of a literary text with linguistic means and more specifically, discussing the verbal behaviour of the national and ethnic stereotypes of Shavian characters with the help of conversation analysis (including Speech Act theory and Politeness Theory) has been demonstrated to be a proper 
and legitimate method. What is missing from the earlier description of Shaw's work (and to my knowledge, utterly absent from research on Shaw's plays) is the discussion on the relationship between his complex ideology and its manifestation in the language of his plays. The micro-sociolinguistic, pragmatic analyses of the plays have demonstrated that the playwright's complex, ambiguous, paradoxical attitude does appear in the linguistic behaviour of the characters, as expressions of their identity, in the form of ambiguous, paradoxical ethnic identities. The linguistic approach has been proved to be more rigorous in manner than literary methods and has given a new perspective to the interpretation of the Shavian plays. In my analyses I have found evidence for the issues brought by literary criticism (Shaw's plays as plays of ideas, his mastery of paradox and irony) but I have also come to findings that only the linguistic analyses were able to bring to the surface in the form of parallel and paradoxical identities.

\section{Conclusions}

In this paper I have outlined an interdisciplinary approach to ethnic identity, relying particularly upon theories from linguistics (especially microsociolinguistics, pragmatics and discourse analysis), sociology, anthropology, and cognitive psychology (in particular, stereotype theory). I have attempted to explain how characters are constructed in their face-to-face interaction with each other. In the pragmatic analysis of the Shavian plays I have tried to explore the dynamics of dialogue conceived as verbal interaction, having implications for the author's character treatment as well as his own ideological, cultural, ethnic identity.

\section{References}

Brown, Penelope and Stephen Levinson. 1987. Politeness: Some Universals in Language Usage. Cambridge: Cambridge University Press.

Bucholtz, Mary and Kira Hall. 2005. Identity and interaction: a sociocultural linguistic approach. Discourse Studies 7 (4-5): 585-614.

Culler, Jonathan. [1975], 2008. Structuralist Poetics. London and New York: Routledge.

Doyle, Brian. 1989. English and Englishness. London: Routledge.

Easthope, Anthony. 1999. Englishness and National Culture. London \& New York: Routledge.

Eco, Umberto. 1990. The Limits of Interpretation. Bloomington: Indiana University Press. Accessed on Google Books 28 September 2009. 
---. 1992. Interpretation and Overinterpretation. Umberto Eco with Richard Rorty, Jonathan Culler, Christine Brook-Rose. Ed. S. Collini. Cambridge: CUP. Accessed on Google Books, 1 October 2009.

Fludernik, Monika. 1993. The Fictions of Language and the Languages of Fiction: The Linguistic Representation of Speech and Consciousness. London: Routledge.

Fox, Kate. 2005. Watching the English: The Hidden Rules of English Behaviour. London: Hodder.

Kelemen, János. 1998. Olasz hermeneutika Crocétól Ecóig [Italian hermeneutics from Croce to Eco]. Budapest: Kávé.

Leech, Geoffrey. 1983. Principles of Pragmatics. London \& New York: Longman.

Lucas, John. 1990. England and Englishness. Ideas of Nationhood in English Poetry 1688-1900. London: The Hogarth Press.

Mey, Jacob L. 1999. When Voices Clash: A Study in Literary Pragmatics. Berlin / New York: Mouton de Gruyter.

---. 2001. Literary Pragmatics. In Schiffrin D. et al. (eds.), The Handbook of Discourse Analysis, 787-97. Oxford: Blackwell.

Mills, Sara. 2003. Gender and Politeness. Cambridge: Cambridge University Press.

Paxman, Jeremy. 1998. The English: A Portrait of a People. London: Penguin Books.

Tan, Peter K.W. 1998. Advice on doing your stylistics essay on a dramatic text. In Jonathan Culpeper, Mick Short, Peter Verdonk (eds.), Exploring the Language of Drama, 161-71. London \& New York: Routledge.

Toolan, Michael. 1994. Narrative: A Critical Linguistic Introduction. London: Routledge.

Traugott, E.C. \& Pratt, M.L. 1980. Linguistics for Students of Literature. New York: Harcourt Brace Jovanovich, Inc. 